\title{
MAPP v. OHIO: PANDORA'S PROBLEMS FOR THE PROSECUTOR
}

\section{ArLen Specter $\dagger$}

Police practices and prosecution procedures were revolutionized in many states by the holding of the Supreme Court of the United States in Mapp $v$. Ohio that evidence obtained from an illegal search and seizure cannot be used in a state criminal proceeding. ${ }^{1}$ The experiences of law enforcement officials in Philadelphia and recent decisions of many state appellate courts indicate that the imposition of the exclusionary rule upon the states is the most significant event in criminal law since the adoption of the fourteenth amendment. In the past quarter century state criminal procedures have frequently been affected by the expanding interpretation of the due process clause of the fourteenth amendment; but Mapp has rewritten the criminal trial treatise for states which had admitted evidence regardless of how it was obtained.

Extreme consequences have been experienced in former nonexclusionary jurisdictions. The Annual Report of the New York City Magistrates' Courts disclosed that gambling cases dropped thirtyfive percent in the year following the ruling in $M a p p$, a statistical change which is attributed to that decision. ${ }^{2}$ A similar result has occurred in Philadelphia, although specific figures are not available. According to the New York report, the larger number of warrants necessitated by the new ruling has so substantially increased the work of the magistrates' courts that a separate division will probably be required. $^{3}$ In Philadelphia the trial courts, as well as the magistrates' courts, have been inundated by the flood of problems on warrants and motions to suppress resulting from Mapp.

The initial reaction in the Pennsylvania courts was one of dismay. The Superior Court characterized Mapp $v$. Ohio as a "hurricane" which "swept over our fair land last June." 4 One Philadelphia trial court judge was so surprised by the $M a p p$ holding that he said it applied only to Ohio as far as he was concerned until the Pennsylvania

$\dagger$ Assistant District Attorney, Chief of the Appeals Division, Philadelphia County, Pennsylvania. A.B. 1951, University of Pennsylvania; LL.B. 1956, Yale University.

1367 U.S. 643 (1961).

2 N.Y. Times, July 16, 1962, page 1, col. 2.

3 Ibid.

4 Commonwealth v. One 1955 Buick Sedan, 198 Pa. Super. 133, 135 (1962). 
appellate courts told him otherwise. Another Philadelphia County judge, when first confronted with $M a p p$, refused to follow it, reasoning that the new interpretation came from a divided court, and he agreed with the dissenters. A distinguished Pennsylvania jurist and author on criminal procedure questioned "the logic of or the justification for Mapp." 5

In the first days after Mapp, law enforcement officials in Philadelphia were uncertain as to what course to take. Policemen, who for years had presented their evidence in court without any regard to how it had been obtained, could not understand the subtleties of what constituted a legal search and seizure. When some Philadelphia trial judges applied principles from liberal federal decisions on search and seizure, the vice-squad detective and the policeman on the beat could understand neither the logic of what had been decided nor the formula for how to act in the future in order to obtain admissible evidence. One enforcement officer of the Pennsylvania Liquor Control Board turned a phrase on a century old case and called the new national exclusionary rule the "dread Mapp decision."

The defense bar shared in the confusion, but not in the gloom. Cases which appeared hopeless in May of 1961 were won in July, when key evidence was excluded because "the constable had blundered." Within three months after Mapp was decided, the Philadelphia District Attorney's Office circulated a twenty-five page memorandum on the law of search and seizure. While the analysis of cases in the federal courts and the exclusionary states was of some assistance, the memorandum was too long and complicated for the police to digest and too short and shallow to provide answers for the vast majority of problems faced by the Philadelphia trial courts in their efforts to reconcile $M a p p$ with the administration of justice in a metropolis faced with major problems of law enforcement.

The avalanche of search and seizure cases since Mapp has produced procedures and principles of law to guide those states which once admitted unconstitutionally seized evidence. Many state appellate courts have sought to interpret the effect of the new federal rule on their state practices. The crucial impact of Mapp, however, has doubtless been felt in the trial courts and at preliminary hearings in magistrates' courts. Only a small percentage of trial court decisions are reported and, except for scattered observations on magistrates' actions in preliminary hearings, the experience at that level is virtually totally lost.

5 Commonwealth v. Griffith, No. 294, May 1962 Sess., Erie County, Pa., Ct. of Quart. Sess., June 21, 1962, p. 2 n.3 (opinion of Burton R. Laub, J.). 
It is unfortunate that the search and seizure case law at preliminary hearings and in the trial courts cannot be comprehensively catalogued in order to provide precedents for future decisions, and even more importantly, to serve as a basis for evaluating the policy and social justifications for a far reaching decision like Mapp $v$. Ohio. That decision might be reconsidered if sufficient recorded experience were available to illuminate the practical day-by-day consequences of the exclusionary principle.

To shed some light on Mapp's impact on law enforcement in a major city and state which had formerly admitted evidence regardless of the method of seizure, this Article will concentrate on the grass-roots experience in Philadelphia and the reaction, in oral argument as well as written decision, of the Pennsylvania appellate courts. Such an analysis is possible because the Appeals Division of the Philadelphia District Attorney's Office has handled the search and seizure problems as they arose on pretrial motions as well as in appellate arguments. The composite picture shows an evolving state common law on such issues as: what constitutes a reasonable search; the effect of consent on eliminating the need for probable cause; the required contents of a search warrant; and the procedure for raising objections based on Mapp.

\section{Mapp's Specific Mandate}

It is important to bear in mind the precise language of the fourth amendment, which is the primary source for the law on search and seizure.

The right of the people to be secure in their persons, houses, papers, and effects, against unreasonable searches and seizures, shall not be violated, and no Warrants shall issue, but upon probable cause, supported by Oath or affirmation, and particularly describing the place to be searched, and the persons or things to be seized. ${ }^{6}$

Wolf $v$. Colorado ${ }^{7}$ held that the fourth amendment is applicable to the states through the due process clause of the fourteenth amendment, but the Supreme Court there rejected the contention that the "concept of ordered liberty" required exclusion of illegally seized evidence in state criminal proceedings. Mapp reversed $W$ olf, formulating a narrow and specific holding "that all evidence obtained by searches and seizures in violation of the Constitution is, by that same authority, inadmissible in a state court." 8

6 U.S. Const. amend. IV. Many state constitutions have a similar provision. See, e.g., PA. Const. art. I, §8.

7338 U.S. 25 (1949).

8367 U.S. at 655 . 
The opinion of the Court contains numerous indications that it intended to require only the exclusion of evidence obtained as a result of an unreasonable search and seizure, without imposing upon the states the federal standard of reasonableness. The Court referred favorably to the law in many states which already excluded such evidence, although not always on the same standards for exclusion enunciated in the federal courts. The Supreme Court cited ${ }^{9}$ California's adoption of the exclusionary rule in 1955, but California has adopted a complicated standard of reasonableness which differs markedly from federal criteria. ${ }^{10}$ Thus in lauding the states which had adopted the exclusionary rule prior to Mapp v. Ohio, the Supreme Court can be said to have implicitly recognized the right of the states to decide for themselves what constitutes a reasonable search and seizure.

The theory that the state courts have latitude in establishing their own standards of reasonableness is buttressed by two principles reaffirmed in Mapp. First, "the very essence of healthy federalism depends on the avoidance of needless conflict between state and federal courts." 11 That maxim suggests that the states may be able to satisfy minimal due process standards without measuring up to federal rules as to what is a reasonable search and seizure and what search warrants must contain. Second, in imposing the exclusionary rule on the states, the Court waited until the states had had an "adequate opportunity to adopt or reject . . ." 12 it on their own. Now that Mapp has been decided, the same attitude of judicial restraint should constrain the Court to give the states a chance to acclimate themselves to the exclusionary rule according to their own standards of reasonableness before federal criteria are imposed.

That the states have the right to decide what is "reasonable" in the law of search and seizure is further supported by the doctrine that the states retain all the rights possessed by them before the most recent United States Supreme Court decision, except that authority which the ruling specifically abrogated. If an area of authority is not explicitly taken away from the states by an expanded interpretation of the due process clause of the fourteenth amendment, then the state retains it. This is the basic concept of the tenth amendment. While the tenth amendment has shrunk in importance in direct pro-

\section{${ }^{8}$ Id. at 651.} 1961).

10 See People v. Ruiz, 196 Cal. App. 2d 798, 16 Cal. Rptr. 855, 858 (Dist. Ct. App.

11367 U.S. at $657-58$.

$12 I d$. at 654 . 
portion to the expansion of the fourteenth, it is still a basic underpinning of our federal system.

In addition, the step by step case approach which culminated in the Mapp decision and the specific holding of Mapp itself indicate a deliberate design on the part of the Supreme Court to do no more than exclude illegally seized evidence in a state proceeding, leaving it up to the state to determine the legality of the seizure within broad "due process" limits.

The California courts have expressly decided that Mapp $v$. Ohio leaves them free to use their own standards for what constitutes probable cause, stating:

We find nothing in Mapp v. Ohio . . . to indicate that as a result of that decision the states are bound to follow the federal requirements of reasonable and probable cause instead of their own. ${ }^{13}$

The Pennsylvania Superior Court, by inference, has reached the same conclusion in Commonwealth $v$. Richards, ${ }^{14}$ which involved the first substantive ruling on search and seizure by a Pennsylvania appellate court after Mapp. Responding to argument on the issue of how far Mapp went in imposing federal law on the states, the Pennsylvania Superior Court declared:

As we view it, the Mapp decision went no further than to hold that, where the search and seizure were unreasonable under all the circumstances, evidence obtained thereunder must, under the Fourteenth Amendment, be excluded in state criminal prosecutions. ${ }^{15}$

The Superior Court declared that the test for reasonableness depended on the "totality of facts" ${ }^{16}$ since "the Mapp decision did not, as we interpret it, preclude judicial determination of what constitutes a reasonable search and seizure under all the circumstances." 17

\section{The Pennsylvania Supertor Court's Rulings on Probable Cause}

For the initial tests of post-Mapp search and seizure, the District Attorney's Office of Philadelphia County chose the cases of Common-

13 People v. Tyler, 193 Cal. App. 2d 728, 734, 14 Cal. Rptr. 610, 613 (Dist. Ct. App. 1961); accord, People v. Rucker, 17 Cal. Rptr. 98 (Dist. Ct. App. 1962). 1962.

$14198 \mathrm{~Pa}$. Super. 39 (1962), petition for allocatur filed, Pa. Sup. Ct., June 21,

15 Id. at $42-43$.

$16 \mathrm{Id}$. at 46.

$17 \mathrm{Id}$. at 42 . 
wealth v. Richards ${ }^{18}$ and Commwealth v. Bosurgi, ${ }^{18}$ from which the prosecution had a right of appeal. These cases were carefully selected because both involved serious offenses of which the defendants were obviously guilty. The factual situations were not extreme but had the potential to establish important principles in the areas of greatest concern to law enforcement agencies.

\section{A. Search of Premises}

Commonwealth $v$. Richards presented an ideal case for appeal. The defendant had been found guilty by the trial judge, sitting without a jury, on charges of possession of drugs, resisting arrest, and assault and battery. The trial court, however, granted defendant's motion in the arrest of judgment ruling that the key evidence, marijuana, had been obtained as a result of an unreasonable search and seizure.

Acting on information received from a reliable informant that the defendant had narcotics in his apartment, officers of the narcotics squad had gone to the building where they were admitted to the first floor by another tenant. Proceeding to the second floor, they had encountered the defendant, who, after resisting, was arrested. Reacting to defendant's shouts of "They're here," the officers had kicked open the door of his apartment in time to observe another man dive head first through a window with a paper bag. Marijuana was later found in both the bag and the apartment. Without that evidence, the conviction could not stand.

The procedural setting made available to the Commonwealth the well-established rule that the District Attorney can appeal from an order arresting judgment after a guilty verdict. ${ }^{20}$ Moreover, the law is firmly established that after a guilty verdict, the court on appeal accepts as true all of the Commonwealth's evidence upon which the trier of fact could properly have based its verdict.

The Superior Court, in reversing, held that the seizure of evidence was reasonable as there was probable cause, based on the reliable informant's report, to believe that the defendant had committed and was continuing to commit a felony. The court equated probable cause with reasonable grounds to believe that the person arrested and searched had

$18198 \mathrm{~Pa}$. Super. 39 (1962). 1962.

$19198 \mathrm{~Pa}$. Super. 47 (1962), allocatur granted, No. 381, Pa. Sup. Ct., July 17,

20 Commonwealth v. Wallace, 114 Pa. 405, 6 Atl. 685 (1886); Commonwealth v. Obenreder, 144 Pa. Super. 253, 19 A.2d 497 (1941). 
committed a felony. Upon the authority of Draper $v$. United States, ${ }^{21}$ it said:

Probable cause exists where "the facts and circumstances within [the arresting officers'] knowledge and of which they had reasonably trustworthy information [are] sufficient in themselves to warrant a man of reasonable caution in the belief that" an offense has been or is being committed. ${ }^{22}$

Accepting the reasoning of United States $v$. Rabinowitz, ${ }^{23}$ the Superior Court also expressly rejected argument based on the contention that the officers had had ample time to obtain a search warrant, stating that the legality of a search depends upon reasonableness under all the circumstances and not solely upon the practicability of procuring a search warrant.

\section{B. Search of the Person}

Commonwealth $v$. Bosurgi, ${ }^{24}$ argued and decided simultaneously with Richards, was a case of extreme importance to the District Attorney's Office from both procedural and substantive viewpoints. ${ }^{25}$ On the day after the burglary of a wholesale jewelry house, an informant had told the investigating detective of a man in a taproom near the scene of the crime who was attempting to sell watches. $\mathrm{He}$ had also provided a detailed description. Not finding anyone fitting the description at the designated bar, the detective had entered another tavern nearby where he noticed the defendant who matched the description. The officer approached the defendant, asked his name, and then patted him down to determine whether he was armed. Feeling bulky objects in Bosurgi's pockets, the detective found watches, some of which came from the jewelry store. Subsequent investigation at the police station uncovered particles of the plate glass window from the burglarized store on Bosurgi's trousers. Following the indictment of Bosurgi for burglary, his counsel filed a pretrial motion to suppress evidence alleging that it was obtained by the police as a result of an unlawful search and seizure. The Court of Quarter Sessions granted the motion after a pretrial hearing on the limited question of the detective's probable cause for searching Bosurgi.

Without the suppressed evidence, the Commonwealth would have been compelled to nolle prosequi the case. Accordingly, a decision was

21358 U.S. 307 (1958).

$22198 \mathrm{~Pa}$. Super. at 45.

23339 U.S. 56 (1950).

$24198 \mathrm{~Pa}$. Super. 47 (1962).

25 The procedural questions are discussed in the text accompanying notes 121, 123-27 infra. 
reached to take an appeal in order to determine the procedural right of the Commonwealth to appeal from a pretrial order suppressing evidence and to resolve important substantive questions concerning search of the person.

On the merits, the Superior Court held that the search was reasonable since the police officer had probable cause to believe that the defendant had committed a felony. The Assistant District Attorney had argued alternatively that the detective had probable cause to think Bosurgi had committed a felony and therefore the search was legal as incidental to the arrest, and even if probable cause to believe that the defendant had committed a felony was lacking, the search was legal because the officer had probable cause to suspect the defendant of having committed a burglary. With the second alternative, the District Attorney's Office sought to persuade the court to rule that a legal search may be made without that degree of probable cause necessary to justify an arrest if circumstances arouse reasonable suspicion that the defendant has committed an offense. This should be sufficient to justify an officer in searching the defendant. If the search discloses incriminating evidence, the defendant could be arrested. Under this theory the essential test of the reasonableness of a search and seizure would turn on whether there was sufficient cause to suspect the defendant of committing an offense rather than whether there was probable cause to arrest the defendant.

The Superior Court by-passed the Commonwealth's "suspicion" theory by holding that the police officer had reasonable grounds to believe that the defendant had committed a felony. The court based that conclusion on the fact that the officer knew a burglary had been committed in the immediate vicinity; that he had received information describing the defendant in detail; and that the defendant was selling watches in the vicinity of the burglary. Under that "totality of facts," the court ruled that the officer had probable cause and reasonable grounds to believe that the defendant had committed the crime and, therefore, to arrest him. The officer's patting down the defendant in order to determine whether he was armed may have been an important factor in Bosurgi. There is some suggestion that a seizure may be justified where objects are found by an officer in patting down a defendant to see if he is armed.

On only one occasion have the seven Superior Court judges agreed on the factual application of the doctrine of probable cause. In Commonwealth $v$. Johnson, ${ }^{28}$ a unanimous court affirmed per curiam the

2627 Pa. D. \& C.2d 301 (Philadelphia County Q. Sess. 1961), aff'd per curian, $198 \mathrm{~Pa}$. Super. 51 (1962), petition for allocatur filed, Pa. Sup. Ct., June 21, 1962. 
decision of the Court of Quarter Sessions of Philadelphia County, in which the search of a narcotics addict was upheld. In that case, the police officer testified that he had observed the defendant alight from a bus arriving from New York City at the Philadelphia Terminal, and look around as if stunned or in the dazed condition characteristic of narcotic addicts. Based on his experience of over four years of observing drug addicts, the officer had concluded that the defendant was under the influence of narcotics. A search undertaken after Johnson had been taken into custody disclosed a cellophane packet of heroin concealed in his hat band. The trial court, and later the Superior Court, held that the search, without a warrant, was proper as incidental to the arrest which in turn was justifiable under the Pennsylvania rule that a police officer may arrest upon the reasonable belief that a felony has been committed. A crucial factor in the lower court's evaluation was that the police officer had probable cause to believe that a felony was being committed based on the officer's extensive experience with narcotic addicts. It ruled that what constitutes probable cause must be determined from the standpoint of the officer considering his unique skill and knowledge, rather than from the standpoint of the average citizen. Another important factor was that the officer, in proceeding to the Philadelphia Bus Terminal, had acted "on information received." 27

\section{Search of Automobiles}

After defining probable cause with respect to search of a dwelling in Richards and considering reasonableness as it affected the search of an individual in Bosurgi, the Superior Court defined probable cause as that concept relates to an automobile in Commonwealth v. One 1955 Buick Sedan. ${ }^{28}$ That case arose in a slightly different setting-a forfeiture proceeding for use of an automobile to transport whiskey unlawfully.

As the result of information that there was an odor of alcohol in the area, two police officers observed a house for several days. On the fourth day, a Buick sedan, operated by a known violator of the liquor laws, drove up to the premises. After remaining in the house for about an hour, the driver made several trips between the house and car; on the last, he carried a carton which he placed on the back seat and drove away. The officers followed and then stopped the automobile. On the back seat they found four one-gallon jugs of white untaxed whiskey. The operator was arrested, his car subjected to a 
search, and the automobile seized, all without a warrant. Afterward the officers obtained a search warrant for the premises which had been under surveillance, where they found a still. The operator's petition for the return of his car was denied by the Court of Quarter Sessions of Philadelphia County, and that order was affirmed by the Superior Court.

In holding that the search and seizure were reasonable, the Superior Court adopted the distinction made by the Supreme Court of the United States in Carroll $v$. United States, ${ }^{29}$ that different considerations apply to a search of a vehicle than of a residence. The court reasoned that it was not practicable to secure a search warrant for a vehicle because it could be quickly moved out of the locality or jurisdiction, and therefore upheld the legality of the search and seizure, stating:

It would have been unreasonable to expect the officers to go some distance away and obtain a warrant for search and seizure when the moving automobile, within a few minutes, probably would have been out of reach of the officers. ${ }^{30}$

The reasonableness of the search of a stationary automobile, without any opportunity to move, was considered in Commonwealth $v$. Czajkowski. $^{31}$ Despite certain procedural problems, ${ }^{32}$ the Superior Court considered the case on the merits and upheld the legality of the search and seizure. The undisputed evidence at trial established that the defendant's automobile was observed in the vicinity of a department store at the time a burglary was being committed. The automobile was parked in a peculiar position approximately one hundred yards from the store. At one point the officer noticed the car lights being flashed on and off, saw two men in the automobile as it moved parallel to the department store's parking lot, and then three men in the automobile. From the license number, the officer determined that the automobile belonged to the defendant, who was apprehended on the following day. An examination of his automobile by the police disclosed pieces of firewall and an innerplate from the safe which had been opened during the burglary.

On these facts, the Superior Court held that the police clearly had probable cause and reasonable grounds to search the automobile incident to the arrest of the defendant. Rejecting the contention that the officers had an opportunity to obtain a search warrant, the court

29267 U.S. 132 (1925).

$30198 \mathrm{~Pa}$. Super. at 140.

$31198 \mathrm{~Pa}$. Super. 511 (1962).

32 See note 112 infra and accompanying text. 
said that the legality of the search turned on its reasonableness and propriety under all the circumstances rather than on the practicability of obtaining a search warrant, emphasizing that "an automobile as a vehicle of transport which moves about readily is in a distinct category on the question of a reasonable search and seizure." ${ }^{33}$ The two dissenting judges expressed the view that there had been ample time to secure a search warrant since there was no chance that the defendant would remove the car before a search warrant could be obtained. ${ }^{\mathbf{3 4}}$

\section{Probable Cause Considered by Pennsylvania Trial Courts}

The Pennsylvania trial courts have also defined probable cause in a variety of factual situations. Like the federal courts and state appellate courts, they are as badly divided on what facts constitute probable cause as they are in complete agreement on the generalized principles of that concept. An analysis of numerous decisions by the judges of the courts of quarter sessions and oyer and terminer in Pennsylvania generally, and Philadelphia County specifically, discloses that the judges are consistent in their own rulings and at odds with their fellow judges in applying the principles in practice.

\section{A. In General}

An extensive analysis of federal law and Pennsylvania law, before Mapp, is contained in Commonwealth v. Silverberg. ${ }^{35}$ In that case, a reliable informant had tipped off the police that the defendant would make a marijuana sale on a certain corner in Philadelphia at a designated time. Believing that a drug transaction was about to take place, an officer apprehended the defendant and conducted a search which disclosed not marijuana, but a blackjack. The defendant was indicted for carrying a concealed deadly weapon, and a motion to suppress the evidence followed.

The court denied the motion, ruling that reasonable cause deals with probabilities judged in terms of practical considerations of everyday life on which reasonable and prudent men act. Recognizing that probable cause could not be determined by any fixed formula, the court cited Brinegar $v$. United States ${ }^{36}$ for the proposition that probable cause exists where the facts and circumstances within the arresting officer's knowledge and of which he has reasonably praiseworthy information are sufficient to justify a man of reasonable caution to believe that

$33198 \mathrm{~Pa}$. Super. at 516.

$34 \mathrm{Id}$. at 517 (dissenting opinion by Watkins, J., joined in by Flood, J.).

35 No. 1586, April 1962 Sess., Philadelphia County, Pa., Q. Sess., June 18, 1962. 36338 U.S. 160 (1949). 
an offense has been or is being committed. Similarly, under Pennsylvania law, probable cause is recognized where there are reasonable grounds for suspicion, supported by circumstances sufficient to warrant an ordinarily prudent man in the same situation in believing the accused party is guilty of the offense charged. ${ }^{37}$

The next question considered in Silverberg was whether hearsay information provided a sufficient basis for the officer's conclusion that probable cause existed. On this issue, the court relied on Commonwealth $v$. Schwartz. ${ }^{38}$ There, the Superior Court concluded that a police officer, seeking a search warrant, need not have personal knowledge of the alleged violations of law so long as he is satisfied that his information was provided by credible persons who had dealings with the defendant at the place specified in the warrant. The Silverberg court further observed that federal authorities were in accord since the United States Supreme Court had specifically upheld the issuance of a search warrant even though the police officer based his conclusion that the requisite cause existed on hearsay information supplied to him by an informant. ${ }^{38}$ To the federal and state authorities cited, the court added an additional requirement of its own which it said was dictated by research although no specific authority was cited: "[T]he record must show that the police officer relied upon the informer to the extent that he reasonably believed the law had been violated." 40 The final conclusion was that it was immaterial that an object other than the one which the officer sought was found, nor was it crucial that the officer failed to obtain a warrant even though he had time to do so.

On the day following its decision in Silverberg, the same court suppressed evidence in another case, holding that it was obtained as a result of an unreasonable search and seizure. ${ }^{41}$ Two police officers had searched the defendant's person and the automobile in which he was sitting, finding numbers paraphernalia which led to his arrest and indictment for setting up and maintaining an illegal lottery. The officers testified that they had kept certain premises under surveillance. They had observed the defendant make numerous stops and then proceed to the premises under surveillance from which he later emerged. The court began with the proposition that a search without a warrant is

37 See Commonwealth v. Ioesel, 155 Pa. Super. 461, 38 A.2d 523 (1944); Reby v. Whalen, $119 \mathrm{~Pa}$. Super. 476, 179 Atl. 879 (1935).

$3882 \mathrm{~Pa}$. Super. 369 (1923).

39 Jones v. United States, 362 U.S. 257, $267-72$ (1960).

40 No. 1586, April 1962 Sess., Philadelphia County, Pa., Q. Sess., June 18, 1962 , p. 5 .

41 Commonwealth v. Brockington, No. 902, Oct. 1961 Sess., Philadelphia County, Pa., Q. Sess., June 19, 1962. 
invalid unless incidental to a lawful arrest. Reasoning that the lottery offense is only a misdemeanor in Pennsylvania so that the police officer must actually see the crime committed in his presence to make a valid arrest, the court held that the search and seizure was illegal.

The case of Commonzealth v. Griffith, ${ }^{42}$ in Erie County, produced a well reasoned opinion on the question of probable cause for search and seizure. Griffith was struck on the back of the head and knocked unconscious by an unknown assailant. The policeman who arrived at the scene found that Griffith had been drinking, was covered with blood from a scalp wound, and was unable to identify even the municipality in which he was found. One of the officers, who was placing Griffith in a police vehicle to be taken to the local hospital for treatment, felt a gun inside his pocket. Griffith was then searched, and a loaded pistol was discovered, leading to the charge of violation of the Uniform Firearms Act.

The court held the search and seizure legal on the ground that the officer had a duty to search the defendant and seize the gun when, in the exercise of his sensory faculties, the officer discovered that the law was being violated in his presence. That conclusion was required, said the court, by the practical necessities of removing the gun expeditiously to prevent possible dire consequences if the defendant had an inclination to use it to obtain his release.

The opinion also suggested an interesting alternative ground for justifying the search and seizure arising out of the defendant's incapacitation. The defendant might have been in need of some special medical attention, such as treatment for an allergy, diabetes, laryngeal difficulties, or in need of blood transfusion, any one of which might have been disclosed by a card in his possession. This factor of modern life, reasoned the court, has "created an absolute necessity for personal searches by those who come to the aid of stricken unfortunates." 43

In concluding that the search was not violative of the federal constitution, the court made some important observations on the need to obtain a search warrant under such circumstances. It rejected the suggestion that one of the officers should have gone to obtain a warrant while the second officer stayed with the defendant, because there was no question but that the concealed article was a gun which was known to the officer at the time of its detection. The court further stated that search warrants are authorized only for places and not for persons. Moreover the search of defendant's person was legal because supported by ample probable cause. If the officer had the requisite probable cause

42 No. 294, May 1962 Sess., Erie County, Pa., Q. Sess., June 21, 1962.

43 Id. at 5-6. 
to obtain a search warrant, then he had the necessary cause to make a search without a warrant. The essential question is whether there was probable cause either for obtaining a warrant or for a search without a warrant. Thus, if probable cause existed, there was no real reason to delay the search to obtain a warrant. If this reasoning is sound then there would be no need to obtain a search warrant in any situation since the probable cause which would support a search with a warrant would support one without a warrant as well. This reasoning, however, may be limited to searches of individuals.

The issue of what constitutes probable cause was considered at length by the Court of Common Pleas of Mercer County, Pennsylvania, in Commonzealth ex rel. La Camera v. McDougall. ${ }^{44}$ Relying on Commonwealth $v$. Schwartz, ${ }^{45}$ which held that probable cause may be equated with reasonable grounds for belief that an offense has been committed, the court concluded that the standard was satisfied where the police officer had been informed in numerous telephone calls that the defendant was in the gambling business, where the defendant's house was placed under surveillance for several days, and where the officer knew that the defendant made his living from gambling activities.

The doctrine of probable cause has been applied in approximately two hundred and fifty decisions involving searches and seizures in Philadelphia County in the first year following Mapp. These cases, like thousands of others from other courts, produce no litmus tests; but an outline of some of the decisions illustrates the problems and the judicial temperaments in this formerly non-exclusionary state. ${ }^{46}$

Philadelphia trial courts, in dealing with the search of premises, have accepted invitation or consent as justification for a search without a warrant. ${ }^{47}$ Consent obtained by deception, however, has been held to invalidate the search. ${ }^{48}$ Officers who have a warrant cannot search premises which are not described in the warrant. ${ }^{40}$

In dealing with searches of the person, these courts have taken into consideration the time of day at which the search took place. While suspicious conduct late at night may justify a search without a war-

44 No. 108, Dec. 1961 Sess., Mercer County, Pa., C.P., Nov. 7, 1961.

$4582 \mathrm{~Pa}$. Super. 369 (1923).

46 These summaries are based on notes of testimony (where available) and police reports.

47 See Commonwealth v. Lloyd, Nos. 21-22, July 1961 Sess., Philadelphia County, Pa., Q. Sess., March 16, 1962.

48 Commonwealth v. Wright, Nos. 862-65, Nov. 1961 Sess., Philadelphia County, Pa., Ct. Oyer \& Terminer, June 8, 1962, appeal docketed, No. 380, Jan. 1962 Sess.,

Pa. Sup. Ct., July 17, 1962 .

40 Commonwealth v. Padulese, Nos. 252-54, June 1961. Sess., Philadelphia County, Pa., Q. Sess., January 8, 1962. 
rant, ${ }^{50}$ suspicious conduct at other times, ${ }^{51}$ or a past criminal record may not. ${ }^{52}$

The Philadelphia courts have been fairly consistent in upholding searches of automobiles without warrants. ${ }^{53}$ The fact that two men were sitting in the front seat of an auto, acting suspiciously, however, was held to be insufficient grounds for a search. ${ }^{54}$

\section{B. The "Routine" Car Stop and Motor Vehicle Code Violations}

There has been general agreement among the judges of the Philadelphia Court of Quarter Sessions in cases of what is known as the "routine" car stop. Most of these have resulted in the suppression of the evidence on the theory that if the officer had no probable cause for the search prior to the time incriminating evidence was seized, the search may not be pulled up by its own boot straps based on the incriminating evidence which it uncovers. ${ }^{55}$

A more complicated question arises when officers, stopping a motorist for a violation of the Motor Vehicle Code, search his car and seize incriminating evidence totally unconnected with the violation for which he was initially stopped. The Philadelphia Court of Quarter Sessions has generally disfavored such a procedure, ${ }^{56}$ although it did validate such a search where the evidence indicated that the operator had consented. ${ }^{57}$

In a lecture at the District Attorneys' Convention at Wernersville, Pennsylvania, on July 11, 1962, Judge Burton R. Laub suggested the theory that the search of an automobile should be justifiable without

50 Commonwealth v. Borek, Nos. 1052-53, July 1961 Sess., Philadelphia County, Pa., Q. Sess., March 16, 1962; Commonwealth v. Copeland, No. 22, Jan. 1961 Sess., Philadelphia County, Pa., Q. Sess., April 13, 1962.

51 Commonwealth v. Esposito, No. 228, Feb. 1962 Sess., Philadelphia County, Pa., Q. Sess., June 19, 1962; Commonwealth v. Lindsay, No. 1212, May 1961 Sess., Philadelphia County, Pa., Q. Sess., March 16, 1962.

52 Commonwealth v. Alston, No. 419, April 1961 Sess., Philadelphia County, Pa., Q. Sess., Feb. 2, 1962.

53 See, e.g., Commonwealth v. Major, Nos. 1297-98, Sept. 1961 Sess., Philadelphia County, Pa., Q. Sess., Feb. 9, 1962; Commonwealth v. McGonigle, No. 1589, May 1961 Sess., Philadelphia County, Pa., $Q$. Sess., Nov. 25, 1961 ; Commonwealth v. Bryant, No. 857, Dec. 1961 Sess., Philadelphia County, Pa., Q. Sess., April 19, 1962; Commonwealth v. Craig, No. 697, Jan. 1962 Sess., Philadelphia County, Pa., Q. Sess., June 30, 1962.

54 Commonwealth v. Temple, No. 916, Feb. 1962 Sess., Philadelphia County, Pa, Q. Sess., June 8, 1962.

55 See, e.g., Commonwealth v. Peoples, No. 1879, Oct. 1961 Sess., Philadelphia County, Pa., Q. Sess., March 2, 1962; Commonwealth v. D'Amore, Nos. 821-22, June 1961 Sess., Philadelphia County, Pa., Q. Sess., March 30, 1962; Commonwealth v. Irvin, No. 1997, May 1961 Sess., Philadelphia County, Pa., Q. Sess., Feb. 16, 1962.

${ }^{56}$ Commonwealth v. Isley, No. 1120, Oct. 1961 Sess., Philadelphia County, Pa., Q. Sess., March 27, 1962; Commonwealth v. Roney, No. 742, Dec. 1961 Sess., Philadelphia County, Pa., Q. Sess., Dec. 22, 1961.

57 Commonwealth v. Mason, No. 845, March 1962 Sess., Philadelphia County, Pa., Q. Sess., June 30, 1962. 
a showing of any special cause by virtue of the motorist's using state highways. It was his view that while the federal government cannot imply consent to search a motorist's car from his use of a state highway, the state can, since the highway is the state's and the use of it is a privilege rather than a right. This, Judge Laub reasoned, would be very similar to the right of the federal government to search an individual entering the United States from a foreign country without any reason for suspecting irregularity.

Judge Laub further suggested that if the courts could not construe the implied consent on their own authority, this might be a proper subject for legislation framed as an amendment to the Motor Vehicle Code. Under such a statute the motorist would be deemed to grant state law enforcement officials the right to search his car without any special reason, in return for the privilege of operating the motor vehicle within the Commonwealth. This implied authorization would be similar to that of the Non-Resident Motor Vehicle Statute under which a non-resident of Pennsylvania who drives within the state is deemed to have authorized the Secretary of the Commonwealth to accept service of legal process against him for any suit instituted as a result of an automobile collision while the motorist was within Pennsylvania.

While this is an interesting and unique theory, it is very doubtful that such a doctrine would withstand the scrutiny of the United States Supreme Court in view of the evolving attitude evidenced by Mapp $v$. Ohio. It is probable that the Court would view an individual's use of the highway as a right, rather than a privilege, so that waiver of the constitutional protection against unreasonable search could not be implied. The reaction of the Philadelphia Quarter Sessions' judges in striking down seizures based on "routine" car stops and searches following violations of the Motor Vehicle Code suggests that the Philadelphia judiciary would also not be inclined to construe liberally an officer's right to stop a car and search the motorist under Judge Laub's novel theory.

\section{C. "Routine" Person Stops}

Most of the decided cases have resulted in the suppression of evidence obtained as a result of the search of an individual following a "routine" person stop. This is so even though the hour of the search was late or the defendant had a previous record. ${ }^{58}$

Some judges of the Philadelphia Court of Quarter Sessions, however, have upheld searches of persons when there were some, although

58 Commonwealth v. Kessler, Nos. 1415-17, Oct. 1961 Sess., Philadelphia County, Pa., Q. Sess., March 23, 1962; Commonwealth v. Stewart, No. 768, Aug. 1961 Sess., Philadelphia County, Pa., Q. Sess., March 9, 1962. 
not very many, additional circumstances. In Commonzealth $v$. Richardson, ${ }^{59}$ the police, after receiving information from an informant, stopped the defendant walking along the highway and found a revolver on his person. A motion to suppress the evidence was denied. A similar ruling was handed down in the case of Commonzuealth $v$. Morton. ${ }^{60}$ Officers had observed a pedestrian at an intersection at approximately 10:30 p.m. walking towards them. When the officers were within view of the defendant, he turned and walked the other way. The officer stopped the defendant, searched him, and seized a .22 caliber revolver. In justifying their actions, the officers testified that their suspicions were aroused because there had been a number of strong-arm robberies in the area. The Richardson and Morton cases may be distinguished from the other "routine" person stops on the ground that the hour of the night, combined with the location, created probable cause for the search and seizure without any additional factors. The court could take judicial notice of the frequency of robberies and muggings in the areas of Philadelphia involved. This may have been the rationale of these rulings, although no reasons were given.

One type of person stop in certain slum areas of Philadelphia consistently results in suppression of evidence. The indigent residents are often found with untaxed liquor. It has therefore become a common police practice to stop anyone seen in these areas with a bag which might contain such contraband. These cases consistently result in suppression of the evidence. A classical illustration is Commonwealth v. Halsell ${ }^{\mathbf{B} 1}$ where the hearing on the motion to suppress took a matter of seconds and is contained on two-thirds of a single page of notes of testimony.

\section{Scope of Search Incidental to Arrest}

The scope of search incidental to an arrest was the subject of an illuminating opinion in Commonzealth $v$. Donahue, ${ }^{62}$ which involved poolselling, bookmaking, conspiracy, and keeping and maintaining a gaming house. A woman arrested in a hotel office stated that she placed bets by phoning the defendant, who occupied a room in the hotel. The officers then proceeded to the room where they found Donahue with a slip of paper containing a list of telephone numbers. 1962.

59 No. 1068, March 1962 Sess., Philadelphia County, Pa., Q. Sess., April 13, 1962.

60 Nos. 1990-91, May 1961 Sess., Philadeiphia County, Pa., Q. Sess., June 30,

61 No. 845, Jan. 1962 Sess., Philadelphia County, Pa., Q. Sess., March 30, 1962. 1961.

62 Nos. 1390-92, April 1961 Sess., Philadelphia County, Pa., Q. Sess., Dec. 28, 
The telephone rang and an officer took telephone numbers from the caller. It was then ascertained that the hotel room was being used as a relay office where horse bettors called to give only the number from which they were calling. The telephone numbers were then relayed to the bank which telephoned the players to secure the bets.

At the trial the defendant's motion to suppress the paper containing the telephone numbers was denied. Starting with the proposition that no warrant is required for a search incidental to valid arrest, the court ruled that Pennsylvania law permitted an officer to arrest for any misdemeanor committed in his presence. ${ }^{63}$ On the basis of federal precedents, the court concluded that there was a permissible area of search beyond the person proper. The court stated that an officer, incidental to a valid arrest, could properly search premises under the control of the person being arrested, and all parts of the premises used for unlawful purposes. It further held that the facts of the case were distinguishable from Go-Bart Importing Co. v. United States, ${ }^{64}$ and United States $v$. Lefkowitz, ${ }^{65}$ which condemned general exploratory searches with or without a warrant.

\section{EFFEct of Time to Get WarRant}

In evaluating the reasonableness of a search and seizure without a warrant, courts have attached some significance to the time the officer had to secure a warrant. Pennsylvania judges, however, are divided as to whether failure to obtain a warrant when there was time to do so vitiates an otherwise valid seizure. Considering the vacillation of the Supreme Court of the United States on this point, it is not surprising that Pennsylvania courts have not been in agreement. In Trupiano v. United States, ${ }^{\circ 6}$ the Supreme Court held that a valid arrest did not in itself justify a search without a warrant; the prosecution had to show that under the circumstances it was unreasonable or impracticable to require the arresting officer to obtain a warrant. Two years later, however, in United States $v$. Rabinowitz, ${ }^{67}$ the Court ruled that the officers were not bound to obtain a search warrant even if there was time, if the seizure was otherwise reasonable. To allay any doubt of the effect of that holding on Trupiano, the Court expressly stated:

To the extent that Trupiano v. United States, 334 U.S. 699, requires a search warrant solely upon the basis of the practicability of procuring it rather than upon the reasonable-

63 See Commonwealth v. Rubin, $82 \mathrm{~Pa}$. Super. 315 (1923).

64282 U.S. 344 (1931).

65285 U.S. 452 (1932).

66334 U.S. 699 (1948).

67339 U.S. 56 (1950). 
ness of the search after a lawful arrest, that case is overruled. ${ }^{68}$

Such an express ruling on a controversial question should have resolved the issue, but in 1961 the Supreme Court may have revived the Trupiano dictum in Chapman v. United States, ${ }^{69}$ in which it stated:

Here, as in that case, "no reason is offered for not obtaining a search warrant except the inconvenience to the officers and some slight delay necessary to prepare papers and present the evidence to a magistrate. These are never very convincing reasons and, in these circumstances, certainly not enough to bypass the constitutional requirement. No suspect was fleeing or likely to take flight. The search was of permanent premises, not of a movable vehicle. No evidence or contraband was threatened with removal or destruction, except perhaps the fumes which we suppose in time would disappear. ${ }^{70}$

Nevertheless, in two instances, Pennsylvania trial courts have rejected defense arguments based on Trupiano, on the ground that that case was overruled by Rabinowitz. ${ }^{71}$ And in other cases, the Court of Quarter Sessions of Philadelphia County has upheld the validity of searches and seizures notwithstanding the absence of warrants which the police could have obtained. In Commonwealth $v$. Randolph, ${ }^{72}$ an informant who had provided reliable information on approximately twenty previous occasions advised the police that the defendant possessed narcotics at his nearby apartment. Without obtaining a warrant, the police immediately went to the defendant's apartment and there seized narcotics paraphernalia. The trial judge denied defendant's motion to suppress the evidence. The same result was reached in Commonwealth $v$. Kutos, ${ }^{73}$ in which police without a warrant had seized stolen goods from defendant's apartment while he was in custody.

In other decisions of the Pennsylvania trial courts, opportunity to obtain a warrant has apparently been fatal to the admission of evidence seized without one. The Court of Quarter Sessions suppressed important evidence in Commonwealth $v$. Wright ${ }^{74}$ where the police had

$68 \mathrm{Id}$. at 66.

69365 U.S. 610 (1961).

$70 I d$. at 615.

71 Commonwealth v. Silverberg, No. 1586, April 1962 Sess., Philadelphia County, Pa., Q. Sess., June 18, 1962; Commonwealth v. Donahue, Nos. 1390-92, April 1961 Sess., Philadelphia County, Pa., Q. Sess., Dec. 28, 1961.

72 No. 480, April 1962 Sess., Philadelphia County, Pa., Q. Sess., June 29, 1962.

73 No. 1319, Dec. 1961 Sess., Philadelphia County, Pa., Q. Sess., April 18, 1962.

74 Nos. 862-65, Nov. 1961 Sess., Philadelphia County, Pa., Ct. Oyer \& Terminer, June 8, 1962, appeal docketed, No. 380, Jan. 1962 Sess., Pa. Sup. Ct., July 17, 1962. 
returned to the defendant's house without a warrant four hours after he was arrested and then obtained crucial evidence in a felony-murder case. In the colloquy at the hearing on defendant's motion to suppress, the court indicated that its suppression of the evidence was motivated, in part, by the fact that the detectives had an opportunity to get a search warrant before returning. Similar evidence was suppressed in Commonwealth $v$. Cohen. ${ }^{75}$ A druggist reported to the police that he believed the defendant was trying to have a forged prescription for narcotics filled. The doctor, who allegedly had signed the prescription, confirmed the druggist's suspicions. The defendant was detained at the police station while an officer searched his residence, finding marijuana and other narcotics paraphernalia. The defendant's motion to suppress the evidence was granted, presumably on the ground that the officer had ample time to obtain a warrant, although there was no written opinion in this case. In other instances, evidence of possession of numbers paraphernalia, ${ }^{76}$ operation of a still, ${ }^{77}$ and possession of narcotics ${ }^{78}$ was suppressed where no warrant to search the premises had been obtained although the police had had time to do so.

The Pennsylvania Superior Court has already considered this question three times. In Commonwealth $v$. Richards, ${ }^{79}$ it rejected the contention that the officers had ample time to obtain a search warrant, ruling that the validity of a search turns upon the reasonableness under all the circumstances, rather than on the practicability of procuring a search warrant. The same answer to the same argument was expressed in Commonwealth v. Czajkowski, ${ }^{80}$ and Commonwealth v. One 1955 Buick Sedan. ${ }^{81}$ The majority's opinion that it would have been unreasonable to expect the officers to obtain a search warrant in One 1955 Buick Sedan led Judge Watkins, in dissent, to characterize the majority's view as "tortured interpretation of the facts." 82

\section{The Search Warrant}

The requisite contents of a legal search warrant has been a recurrent and torturous problem since $M a p p$. Search warrants have long 1962.

75 Nos. 1515-18, Nov. 1961 Sess., Philadelphia County, Pa., Q. Sess., March 16,

76 Commonwealth v. Samuels, Nos. 158-60, May 1961 Sess., Philadelphia County, Pa., Q. Sess., Jan. 18, 1962.

77 Commonwealth v. Wiggins, No. 178, Oct. 1961 Sess., Philadelphia County, Pa., Q. Sess., March 16, 1962.

78 Commonwealth v. Witherspoon, No. 2239, May 1961 Sess., Philadelphia County, Pa., Q. Sess., Feb. 11, 1962.

$79198 \mathrm{~Pa}$. Super. 39 (1962).

$80198 \mathrm{~Pa}$. Super. 511 (1962).

$81198 \mathrm{~Pa}$. Super. 133 (1962).

82 Id. at 141 (Watkins, J., dissenting). 
been used under Pennsylvania practice, but the formalities of their execution and substance were not scrutinized prior to the time Pennsylvania became an exclusionary state under the mandate of $M a p p$.

\section{A. Magistrates' Practices}

Prior to 1961 it was commonplace to see police officers obtain search warrants from magistrates at divisional police courts before hearings, without being sworn and with very little, if any, information being given to establish probable cause. The informality of police and magistrates' practices was severely criticized in a recent opinion denouncing the issuance of search warrants where the officer was not sworn. ${ }^{83}$ At trial, counsel for defendant Simmons had questioned the police officer concerning the search warrant used to seize numbers paraphernalia essential to the prosecution. On cross-examination the officer admitted that he was not under oath when he requested the search warrant and he could not recall anything he said to the magistrate. The court accordingly ruled that the warrant was invalidly obtained, suppressed the evidence, and discharged the defendant.

The Simmons opinion evoked a sharp reaction among the magistrates; for a time, one magistrate refused to issue warrants under any circumstances. The Philadelphia District Attorney's Office advised the Commissioner of Police about the requirements set forth in Simmons, with which the District Attorney's Office concurred, and since that time there has been no further difficulty on this point.

Early in 1962, however, a serious problem erupted when the magistrates refused to issue search warrants to the police without disclosure of the identity of confidential informants. On the basis of the opinions in Simmons and Commonwealth $v$. Patrone, ${ }^{84}$ the Solicitor for the Board of Magistrates took the position that the magistrates could issue warrants only when competent evidence was presented to them. The Police Commissioner categorically refused to expose his informants on the ground that disclosure would terminate their usefulness. The magistrates countered that the police had to trust them if they were to honor the veracity of the police and issue search warrants. After two warrantless weeks, a meeting of the Police Commissioner and his deputy, the Chief Magistrate and his counsel, the District Attorney and two Assistants, and the City Solicitor and his Assistant finaly resolved the problem. An eight-point agreement was formulated which essentially provided that the warrant should contain specific facts concerning the

83 Commonwealth v. Simmons, 26 Pa. D. \& C.2d 120 (Philadelphia County Q. Sess. 1961).

8427 Pa. D. \& C.2d 343 (Philadelphia County Q. Sess. 1962). 
nature of the investigation and surveillance, the information which was received from any informant, if available, and certification that the offcer requesting the warrant was sworn. The magistrates finally retreated from their insistence that the identity of confidential informants be disclosed, when confronted with the case of United States $v$. Jones, ${ }^{85}$ which held that even under federal law, a commissioner was justified in issuing a search and seizure warrant without the disclosure of the identity of a confidential informant.

\section{B. Substance of the Warrant}

The substance of the search warrant has proved to be a very troublesome problem for law enforcement officials. Prior to Mapp, the closest appellate court decision on what a valid search warrant must contain under Pennsylvania law was Commonwealth v. Schwartz. ${ }^{86}$ The Superior Court there ruled that in the absence of a statute expressly requiring details, it was sufficient for the affidavit to say "that there is probable cause to believe, and that he [the affiant] has just and reasonable grounds for believing and does believe . . . ." The court said, "The affiant is not restricted to violations of law within his own knowledge nor is he bound to set forth the names of witnesses or the details as to what they would testify." 87 The court squarely disagreed with the federal decisions in this field, deciding that Pennsylvania requirements were less stringent than those under federal law; hence the decisions of federal courts as to the essentials of search warrants were of little use in deciding the applicable Pennsylvania rule.

After $M a p p$, however, two Pennsylvania trial courts held insufficient warrants which closely resembled the one considered in Schwartz. ${ }^{88}$ In the section entitled "Probable Cause and/or Reasonable Grounds," one warrant read, "From surveillance and information I have real cause to believe and do believe that this property is being used illegally." 88 Both courts ruled that a search warrant was legally insufficient if it did not contain an adequate statement of supporting facts, and cited federal authority.

The Commonwealth has taken an appeal in the second of these two cases, ${ }^{90}$ which has not yet been decided. It has made three contentions :

85362 U.S. 257, 267-72 (1960).

$8682 \mathrm{~Pa}$. Super. 369 (1923).

87 Id. at $374-75$.

S8 Commonwealth v. Patrone, 27 Pa. D. \& C.2d 343 (Philadelphia County Q. Sess. (1962); Commonwealth v. Griffin, Nos. 2459-61, Jan. 1962 Sess., Philadelphia County, Pa., Q. Sess., June 21, 1962, appeal docketed, No. 321, Oct. 1962 Sess., Pa. Super. Ct., June 22, 1962.

89 Commonwealth v. Patrone, supra note 88 at 344.

90 Commonwealth v. Griffin, Nos. 2459-61, Jan. 1962 Sess., Philadelphia County, $\mathrm{Pa}$. Q. Sess., June 21, 1962, appeal docketed, No. 321, Oct. 1962 Sess., Pa. Super. Ct., June 22, 1962. 
(1) Probable cause in fact existed for the search, and it is not determinative that the details establishing probable cause were not set forth on the fact of the warrant; (2) there is a presumption that a warrant was properly issued, the burden of proof being on the party who seeks to suppress the evidence to establish that probable cause did not exist for its issuance; and (3) the warrant complied with the technical requirements of Pennsylvania law, which differs from federal law.

The question of what facts the search warrant must contain was also the subject of an extensive post-Mapp opinion in Commonwealth ex rel. LaCamera $v$. McDougall. ${ }^{91}$ That case involved a search and seizure after the officer executed an affidavit stating "number slips [are] being delivered or picked up at 917 Fruit Avenue in the City of Farrell" and that "there is just cause to suspect that number slips or some part thereof are concealed in the residence of $\mathrm{Mr}$. and Mrs. LaCamera at that address." These statements are more detailed than those set forth in the two cases discussed, but they do not present the factual details of the officer's observation, surveillance, or investigation as required under those decisions. Recognizing that "the evidence of the alleged fact is not set forth in detail," the court held that "that is not required" based upon the Pennsylvania Superior Court's decision in Commonwealth v. Schwartz, ${ }^{92}$ considered above.

\section{Geographical Scope of the Warrant}

The geographical range of a warrant authorizing a search and seizure was the subject of a cogent opinion in Commonwealth $v$. Tracton. ${ }^{93}$ As a result of investigation of an extensive burglary ring, the police decided to search several premises simultaneously in order to preclude flight and removal of the stolen goods. A search warrant was obtained from a judge of the Court of Quarter Sessions of Philadelphia County for the search of the defendant's home in Philadelphia. When the police arrived at that address, they found that the defendant had moved to Montgomery County. The detective then appeared before a magistrate in Philadelphia who questioned him regarding probable cause. The detective exhibited the warrant obtained from the Quarter Sessions judge and, without being sworn, informed the magistrate generally as to the facts presented to obtain that warrant. The magistrate then issued a search warrant for defendant's premises in Montgomery County.

Responding to defendant's motion to suppress the evidence found in the search, the court noted that the Act of 1722, which granted

91 No. 108, Dec. 1961 Sess., Mercer County, Pa., C.P., Nov. 7, 1961.

$9282 \mathrm{~Pa}$. Super. 369 (1923).

93 Misc. Docket, Philadelphia County, Pa., Q. Sess., June 25, 1962. 
validity to magistrates' subpoenas in any county of the Commonwealth, includes the language "and other warrants." 94 Based on this statutory language and the rationale that search warrants, being of less immediate import than a body warrant, should be no more limited, the court ruled that the warrant was valid. The defendant's argument that the detective's failure to swear to the second warrant was a fatal defect was rejected, on the ground that the matter must be viewed as a continuing one, and the second warrant had no standing without reference to the first which was sworn. It is the facts, reasoned the court, which make the warrant valid rather than the act of swearing. The magistrate had a right to rely on the previous warrant issued by a superior tribunal, and therefore, on the "totality of facts," the warrant was valid and the search was legal.

\section{Consent Eliminates the Need for a Warrant or Probable Cause}

There is a developing doctrine in Pennsylvania that evidence seized without a warrant or probable cause is admissible if obtained with the consent of the defendant or the individual in possession of the seized article. In Commonwealth $v$. Bosurgi ${ }^{95}$ the defendant willingly responded to the detective's request to stand up and turn around, raising no objection to being "patted down." While "consent" was not an alternative holding, it was an important factor in the court's conclusion that the search and seizure was reasonable under all the circumstances. The Superior Court said, "Defendant's compliance and total failure to raise any objection to the officers' search is virtually tantamount to consent." ${ }^{96}$ The Superior Court also emphasized the consensual aspect of the search and seizure in Commonwealth $v$. One 1955 Buick Sedan. ${ }^{07}$ When the operator of the motor vehicle was stopped he merely said, "That's all I have. That's it." From this the court concluded that "At no time did Scott object to the search of his car." 88

Similarly, the question of consent has been considered important in numerous decisions in the Court of Quarter Session of Philadelphia County. In Commonwealth $v$. Heninger, ${ }^{99}$ defendant consented to a search and seizure, but later argued on his motion to suppress the evidence that real consent could not be given while he was in custody.

94 Pa. Stat. Ann. tit. 42, §511 (1930).

$95198 \mathrm{~Pa}$. Super. 47 (1962).

${ }^{86} \mathrm{Id}$. at 50.

$97198 \mathrm{~Pa}$. Super. 133 (1962).

88 Id. at 136.

99 No. 1582, Oct. 1960 Sess., Philadelphia County, Pa., Q. Sess., Jan 6, 1962. 
The court denied defendant's motion without opinion, presumably on the ground that consent to the search and seizure had been given. A motion to suppress has also been denied where petitioner's co-defendant consented to the search and seizure. ${ }^{100}$ In Commonwealth v. Donahue, ${ }^{101}$ the court gave as one reason for upholding the search and seizure the fact that the officers were invited into the hotel room where the search and seizure took place.

The consent doctrine may also apply when a seizure of evidence is made on business premises to which the public is invited. The court in Commonwealth $v$. Snead ${ }^{102}$ refused to suppress evidence obtained without a warrant when the police seized certain evidence in the defendant's second-hand store, although the court did suppress evidence at the same hearing which was obtained from defendant's second floor apartment. The consent which is present in a public store terminates when the officers advance beyond the public portion of the premises. ${ }^{103}$ Consent may also be vitiated if obtained through deception. ${ }^{104}$

\section{The Procedural Problems}

\section{A. A Rule for Pretrial Motions}

The procedural entanglements inspired by $M a p p$ have been almost as troublesome as the substantive issues. Analogizing to Rule 41(e) of the Federal Rules of Criminal Procedure, the District Attorney's Office immediately took the position that the question of an illegal search and seizure must be raised by a pretrial motion to suppress the evidence.

Responding to the procedural confusion, the Committee on the Pennsylvania Rules of Criminal Procedure, which recommends rules of procedure for promulgation by the appellate courts, drafted suggested rules pertaining to search and seizure. As yet the Pennsylvania Supreme Court and Superior Court have not acted on the Cormittee's recommendations. However, on December 15, 1961, the Court of Quarter Sessions of Philadelphia County adopted those rules, designated as numbers 100 and 101. Essentially they provide that:

(1) A defendant must move for suppression of evidence obtained as a result of an illegal search and seizure not later than 5 days before trial.

100 Commonwealth v. Bonner, No. 1582, Oct. 1960 Sess., Philadelphia County, Pa., Q. Sess., June 22, 1961.

1961. 102 Nos. 1428-44, March 1961 Sess., Philadelphia County, Pa., Q. Sess., March 30, 1962.

103 Commonwealth v. Pittman, No. 988, June 1961 Sess., Philadelphia County, Pa., Q. Sess., June 15, 1962.

101 Commonwealth v. Wright, Nos. 862-65, Nov. 1961 Sess., Philadelphia County, Pa., Ct. Oyer \& Terminer, June 8, 1962, appeal docketed, No. 380, Jan. 1962 Sess., Pa. Sup. Ct., July 17, 1962. 'This case is discussed in text accompanying note 48 supra. 
(2) Motions made later than 5 days before trial will be entertained only where opportunity therefore did not previously exist, or the defendant was not aware of the ground for the application, or a prior application for relief had been made but not finally determined, or the interests of justice require it.

(3) A hearing shall be scheduled on the motion at which time evidence shall be taken on the factual averments of the application which are specifically denied by the answer.

(4) If it is determined that evidence was seized in violation of law or the warrant was improperly issued (the warrant being insufficient on its face; issued without probable cause; or illegally executed), then the matter shall not be admitted into evidence and no copy, photograph, reproduction, description, or replica of such property may be admitted into evidence. No testimony or comment shall be received respecting the evidence.

(5) If the county of seizure is different from the county of prosecution, the prosecution county shall be bound by and enforce any order made by a court of the seizure county provided such order commands the return of the property and its suppression as evidence.

(6) When an application for the suppression of evidence is made at trial, the trial judge shall hear the application outside the presence of the jury in the first instance, receiving such evidence as may be necessary for a proper determination of the issue. If there are disputed issues of fact, the trial judge shall permit the jury to hear evidence in which case the matter shall be submitted to the jury for determination as in the case of disputed confessions in criminal cases, with an appropriate interrogatory to be answered by the jury in the event a guilty verdict is returned.

\section{B. Decisions in Magistrates' Courts}

The adoption of Rules 100 and 101 for Philadelphia County has been most helpful, but has not fully solved the search and seizure problems arising in the magistrates' courts. The Court of Quarter Sessions is probably without authority to establish rules for the magistrates, ${ }^{105}$ and Rules 100 and 101 do not purport to bind them.

The search and seizure question is frequently raised before the magistrate at the preliminary hearing which is ordinarily held the morning after the arrest in one of twelve divisional police courts throughout the City of Philadelphia. The cry of Mapp v. Ohio is

105 McNair's Petition, 324 Pa. 48, 55, 187 Atl. 498, 501 (1936). 
raised before the magistrate whenever there is physical evidence, a police officer who seized it, and most important, a defense counsel to object to it. Defendants are not represented by counsel in most preliminary hearings, however, so that the magistrates are rarely confronted with this issue. When they are, the Assistant District Attorney, who attends all such hearings, is instructed to request that the question not be ruled upon by the magistrate, who need not be a lawyer, but be reserved for the Court of Quarter Sessions on a motion to suppress pursuant to Rules 100 and 101. The District Attorney's Office has insisted on this position in view of the complicated factual situations and subtle legal problems which defy solution even after extensive hearings, analysis, briefing, and legal argument before judges learned in the law. Nevertheless, magistrates do on occasion suppress evidence at the preliminary hearing. The rationale for their action, although seldom expressed and probably less frequently understood, is that a defendant may be held for action by the grand jury only if competent evidence is presented at the preliminary hearing. Just as a defendant may not be properly held for court upon hearsay evidence, so the argument goes, a magistrate should not hold a defendant if the evidence is not competent because obtained in violation of the due process clause of the fourteenth amendment.

In those cases in which the magistrate has decided adversely to the Commonwealth, the District Attorney's Office has a remedy by asking for a rearrest. In that event, the defendant is brought before a judge in the Court of Quarter Sessions for a second preliminary hearing. At that time the judge can rule on the search and seizure question in virtually the same way as he would were he considering a pretrial motion to suppress. As a discretionary matter, however, the District Attorney does not seek rearrests in all cases where the magistrate has discharged the defendant; therefore the dispositive order on the constitutional question of search and seizure is sometimes made by the magistrate.

\section{Burden of Proof on Motions To Suppress}

There has been no definitive Pennsylvania decision as to which party has the burden of proving the constitutionality of the search and seizure. Since the defendant is the moving party on the application to suppress, it is logical that the burden should be his, and this is the existing federal rule. ${ }^{100}$ There is, however, some basis for the defense contention that the burden is on the Commonwealth to introduce competent evidence at trial, free from the taint of an illegal search 
and seizure. The Pennsylvania Supreme Court has ruled that the burden of proof is not on the defendant to establish an alibi, but rather the overall burden remains upon the Commonwealth to establish its case beyond a reasonable doubt taking into consideration the alibi defense. The court is required to charge the jury that it may find a reasonable doubt as to defendant's guilt exists by virtue of the defendant's evidence of alibi, notwithstanding the defendant's failure to prove it by the preponderance of the evidence. ${ }^{107}$

It is doubtful, however, that the alibi analogy would lead a court to place the burden on the prosecution to prove that evidence was constitutionally obtained. There is the implicit suggestion in the Superior Court decision in Commonwealth v. Cuff, ${ }^{108}$ that the defendant has the burden of proving that the search and seizure were unconstitutional. In that case the defendant petitioned to vacate a sentence after a robbery conviction. The defendant claimed that his arrest resulted from an illegal seizure of evidence. In denying the petition the court held that Mapp v. Ohio was not applicable since there was no allegation that the defendant's conviction was based solely on the allegedly illegally seized evidence. By inference, that case may stand for the proposition that it is the obligation of the defendant to allege the violation of his constitutional rights and follow up that allegation with proof, although it is hardly determinative on that issue since it arose on a post-conviction motion to vacate.

Several rulings by the Court of Quarter Sessions of Philadelphia County on motions to suppress evidence also indicate that it is the defendant who has the burden of proof. In Commonzealth v. Magnelli, ${ }^{108}$ a pretrial motion to suppress was dismissed with prejudice when defense counsel failed to appear on two consecutive listings of the case. In two other cases, there were dismissals of motions to suppress evidence, without prejudice, when defense counsel failed to appear. ${ }^{110}$ The application to suppress in Commonzealth $v$. Bor ${ }^{111}$ was dismissed without prejudice because no facts were pleaded. These decisions by the Court of Quarter Sessions indicate that the trial judges regard it as the obligation of defense counsel to allege and prove facts in support of motions to suppress evidence.

107 Commonwealth v. Bonomo, 396 Pa. 222, 151 A.2d 441 (1959).

$108196 \mathrm{~Pa}$. Super. 274, 175 A.2d 136 (1961).

109 Nos. 2040-41, Oct. 1960 Sess., Philadelphia County, Pa., Q. Sess., May 4, 1962.

110 Commonwealth v. Rementer, No. 1055, Jan. 1962 Sess., Philadelphia County, Pa., Q. Sess., June 29, 1962; Commonwealth v. Stevenson, No. 509, Feb. 1962 Sess., June $22,1962$. 1962.

111 Nos. 201-03, July 1961 Sess., Philadelphia County, Pa., Q. Sess., March 9, 


\section{Alternative Procedures for Raising Legality of Search and Seizure}

Challenges to a search and seizure have been raised by a variety of procedures in various courts of the Commonwealth. In Conmonwealth v. Czajkowski, ${ }^{112}$ some twelve days before the $M I a p p$ decision, the defendant moved to exclude certain evidence alleging it was obtained under circumstances amounting to an unreasonable search and seizure. The trial court refused to exclude the evidence and subsequently overruled defendant's motions for new trial and in arrest of judgment. On appeal, the Pennsylvania Superior Court ruled that the evidence was obtained legally, thus avoiding the necessity for decision as to whether defendant employed the proper procedure. However, the court did comment by way of dictum that the procedural questions on search and seizure have been left to the states by the Supreme Court of the United States, and that such objections should be made promptly. The Superior Court also noted, with apparent approval, the federal procedure under Rule 41 (e) of the Federal Rules of Criminal Procedure which requires that a motion to suppress evidence be made prior to trial unless the defendant was unaware of the grounds for such a motion.

The legality of a search and seizure has also been tested through a petition for a writ of habeas corpus. ${ }^{113}$ While the defendant was out on bail after the indictment, defense counsel decided to test the legality of the seizure of certain evidence. At his request, the court terminated the defendant's bail and ordered him remanded to custody so that he would be in a legal position to ask for a writ of habeas corpus. Following the hearing, the court again allowed the defendant to be released on bail pending its decision. Despite the District Attorney's objection to the procedure, the court deemed it permissible for the defendant to test the search and seizure question by habeas corpus after surrendering himself, but held that the defendant had acted too late, because the issue must be raised prior to indictment. The court buttressed its conclusion by analogy to Federal Rule of Criminal Procedure 41(e). Notwithstanding this procedural ruling, however, the court considered the case on the merits, concluding that the search and seizure were reasonable.

In a case involving a pretrial petition which asked that the magistrate's transcript be quashed, the defendant be discharged from the obligation of his bond, and the seized gun be returned, the court-though expressing doubt that the defendant had taken the proper procedural

$112198 \mathrm{~Pa}$. Super. 511 (1962).

113 See Commonwealth ex rel. La Camera v. McDougall, No. 108, Dec. 1961 Sess, Mercer County, Pa., C.P., Nov. 7, 1961. 
course, but acting with the consent of the District Attorney-disposed of the case on the merits as though the petition was properly before it. ${ }^{114}$

The constitutionality of the search and seizure was submitted to the jury in the case of Commonwealth $v$. Fiorini. ${ }^{115}$ The jury concluded that the evidence was obtained as a result of a legal search and seizure and convicted the defendant.

Despite the fact that Philadelphia County has a rule of the Court of Quarter Sessions requiring that the motion to suppress be made at least five days before trial, the issue is frequently raised at trial..$^{116}$ If it appears that the trial judge is disposed to consider the search and seizure issue at trial, the Assistant District Attorney will ordinarily object and seek to have defense counsel move to withdraw a juror so that the question may then be placed as a pretrial motion on the miscellaneous list, to be heard in advance of the next trial listing. If heard as a pretrial motion, the Commonwealth's right of appeal is preserved. In at least two cases, this request has been granted.177

In some situations, the trial court has listened to the defendant's objection at the time of trial and deferred adjudication on guilt until a decision was reached on the motion to suppress evidence. This was the procedure followed in Commonwealth $v$. Samuels. ${ }^{118}$ After deferring adjudication, the trial judge, sitting without a jury, found the defendant not guilty in a factual situation which made it clear that the defendant's motion to suppress was granted. In other cases the trial courts have refused to consider defendant's motion to suppress at trial notwithstanding the argument that the Quarter Sessions Rule is ineffectual because a defendant cannot be compelled to waive his constitutional rights. The Philadelphia trial courts have also considered defendant's search and seizure argument on post-trial motions for a new trial or in arrest of judgment. ${ }^{118}$

Most of the possible procedural problems were raised in the case of Commonwealth v. Cabey, ${ }^{120}$ in which defendant objected to the

114 Commonwealth v. Griffith, No. 294, May 1962 Sess., Erie County, Pa., Q. Sess., June 21, 1962.

115 Tried in Berks County, Pa., before Judge Warren $K$. Hess. This information was provided by Assistant District Attorney Peter Cianci at the District Attorneys' Convention, Galen Hall, July 11, 1962.

118 See Commonwealth v. Katz, No. 611, Dec. 1961 Sess., Philadelphia, Pa., County Ct., April 11, 1962; Commonwealth v. Young, No. 315, May 1961 Sess., Philadelphia County, Pa., Q. Sess., Jan. 9, 1962.

117 Commonwealth v. Leach, No. 857, Jan. 1961 Sess., Philadelphia County, Pa., Q. Sess., March 2, 1962; Commonwealth v. Donohue, Nos. 1390-92, April 1961 Sess., Philadelphia County, Pa., Q. Sess., Oct. 9, 1961.

118 Nos. 158-61, May 1961 Sess., Philadelphia County, Pa., Q. Sess., Jan. 18, 1962. 119 Commonwealth v. Patrone, 27 Pa. D. \& C.2d 343 (Philadelphia County Q. Sess. 1962); Commonwealth v. Garnett, No. 1293, April 1961 Sess., Philadelphia, Pa., County Ct., Sept. 18, 1961.

120 Nos. 1003-08, May 1961 Sess., Philadelphia County, Pa., Q. Sess. 
introduction into evidence of a gun seized from a garage which he rented. The objection was first raised at the magistrate's hearing, and there overruled. At the first trial, which resulted in a hung jury, the trial judge sustained the objection of defense counsel to the introduction into evidence of the gun on the ground that the search and seizure were illegal. At the second trial, before another presiding judge, the motion of defense counsel to suppress the evidence was denied; the court stated that its rules required the issue to be raised by a pretrial motion. When the second trial also ended in a hung jury, defense counsel filed a pretrial motion to suppress, which was denied. At the third trial, where the defendant was finally found guilty, the motion to suppress was again renewed, but was denied on the ground that the trial court was bound by the pretrial ruling.

\section{E. Appealability}

The District Attorney's Office of Philadelphia has been successful in obtaining a favorable ruling from the Pennsylvania Superior Court on the important question of the Commonwealth's right to take an appeal from a pretrial order granting defendant's motion to suppress evidence. That right of appeal is crucial since the Commonwealth would be unable to appeal from an acquittal at trial, where the suppressed material left insufficient evidence to warrant a conviction. The right to appeal from the pretrial suppression order complements the local Philadelphia rules requiring that all motions to suppress be made at the pretrial stage. The question of appealability by the defendant from the refusal of Quarter Sessions to suppress evidence in a pretrial proceeding, while superficially similar to the appealability by the Commonwealth from an order suppressing evidence, is realistically different. These two questions were argued and decided on the same day by the Pennsylvania Superior Court in Commonwealth $v$. Bosurgi, ${ }^{121}$ and Commonwealth v. Diggs. ${ }^{122}$

After the District Attorney's Office had filed an appeal from the order suppressing evidence in Bosurgi, defense counsel moved to quash the appeal on the ground that the order was interlocutory. The Commonwealth relied upon certain pre-Mapp suppression cases, ${ }^{123}$ in which the Superior Court had ruled that the Commonwealth had the right of appeal where the order "terminates the prosecution," and "where the 1962.

$121198 \mathrm{~Pa}$. Super. 47 (1962), allocatur granted, No. 381, Pa. Sup. Ct., July 17,

122 No. 141, Oct. 1962 Term, Pa. Super. Ct., March 28, 1962.

123 Commonwealth v. Rich, $174 \mathrm{~Pa}$. Super. 174 (1953) ; Commonwealth v. Richardson, $174 \mathrm{~Pa}$. Super. 171, 100 A.2d 155 (1953); Commonwealth v. Montanero, 173 Pa. Super. 133, 96 A.2d 178 (1953). 
return and suppression of evidence are ordered in terms so broad that the Commonwealth might be prejudiced in an effort to introduce secondary evidence." ${ }^{124}$ Bosurgi presented a clear case of inability to prosecute without items seized as a result of the challenged search.

The defendant contended in his brief and at oral argument that the pretrial order suppressing evidence was not a final disposition of the case and therefore the District Attorney should not have the right of appeal. In support of his position, defendant cited the decision of the Supreme Court of the United States in DiBella v. United States ${ }^{125}$ which was handed down a few days before the Bosurgi argument. DiBella held that the United States Government did not have the right of appeal from a pre-indictment motion which resulted in quashing evidence obtained as a result of an unreasonable search and seizure. The Supreme Court reasoned that the prosecution was no more prejudiced than they would have been as a result of any other adverse evidentiary ruling during trial.

While the implications of DiBella had not been briefed, the District Attorney's Office argued that the federal law on appealability in no way affected the identical question in a state court, because of the language from $M a p p$ : "As is always the case, however, state procedural requirements governing assertion and pursuance of direct and collateral constitutional challenges to criminal prosecutions must be respected." 126 At the oral argument, the Superior Court informally ruled that the Commonwealth had the right of appeal and proceeded to hear argument on the merits. Later, in its opinion, the court specifically held that "Where the order suppressing evidence on the ground it was obtained by illegal search and seizure in effect terminates the prosecution, it is definitive and appealable by the Commonwealth." ${ }^{127}$

When the case of Commonzvealth $v$. Diggs ${ }^{128}$ was called for oral argument a few minutes after the Bosurgi argument was concluded, the Superior Court considered the right of appeal by a defendant whose pretrial motion to suppress evidence had been denied. In this case it was the Commonwealth which had filed a motion to quash the appeal on the ground that the order was interlocutory. The District Attorney's Office distinguished its right to appeal from that of the defendant on the ground that the order denying a motion for suppression of evidence is not a final order as to the defendant since he may continue to trial and be acquitted. And, if the defendant were convicted, he would then

124 Commonwealth v. Rich, supra note 123 , at 178.

125369 U.S. 121 (1962).

126 Mapp v. Ohio, 367 U.S. 643,659 n.9 (1961).

$127198 \mathrm{~Pa}$. Super. at 49.

128 No. 141, Oct. 1962 Term, Pa. Super. Ct., March 28, 1962. 
have the right to appeal and challenge the validity of the ruling on the search and seizure question. The Superior Court ruled from the bench that the defendant did not have the right of appeal.

The question of the defendant's right to take an appeal from the denial of his pretrial motion to suppress evidence was decided by the Pennsylvania Supreme Court in the unreported case of Commonzerealth v. Borum. ${ }^{129}$ Borum, one of the defendants in the In Ho Oh killing, moved to suppress evidence consisting of his trench coat and shoes which his mother had turned over to detectives shortly after his arrest. This case was listed for argument at the April, 1962 Term of the Supreme Court. The Commonwealth moved to quash the appeal summarily without oral argument on the same grounds advanced in Diggs, and the Superior Court's ruling in Diggs was cited as authority. On April 16, 1962 a per curiam order was entered by the Supreme Court of Pennsylvania: "Motion granted: appeal quashed."

The Supreme Court will rule on the right of the Commonwealth to take an appeal from the pretrial order suppressing evidence in two cases which are listed before that Court for argument in November, 1962. Commonwealth v. Cockfield ${ }^{130}$ involves a factual situation where the lower court suppressed evidence consisting of gasoline and other inflammable liquids linking the defendant to an arson-murder. In the case of Commonwealth $v$. Wright, ${ }^{131}$ evidence was suppressed consisting of a rag doll stuffed with money taken in the commission of a robbery-murder. The defense counsel has already filed a motion to quash the Commonwealth's appeal in Cockficld on the ground that there is other evidence on which the District Attorney may base his case including a statement from the defendant. Defense counsel in Wright has also indicated that a motion to quash the appeal will be filed in that case. Cockfield and Wright involve more difficult questions on appealability than did Bosurgi, because the record does not make it clear that the Commonwealth would be out of court without the suppressed evidence. After the Supreme Court decides these cases, Pennsylvania appellate procedure on search and seizure should be settled.

\section{F. Retroactivity}

The most serious possible consequence of Mapp $v$. Ohio, as far as the District Attorney is concerned, would be its retroactive application which would entitle defendants convicted prior to Mapp to obtain their release from prison. If the rule of $M a p p$ establishes a fundamental

129 No. 268, Jan. 1962 Term, Pa. Sup. Ct., April 16, 1962.

130 Nos. 688-94, May 1960 Sess., Philadelphia County, Pa., Q. Sess., appeal docketed, No. 379, Jan. 1962 Sess., Pa. Sup. Ct., July 19, 1962.

131 Nos. 862-65, Nov. 1961 Sess., Philadelphia County, Pa., Q. Sess., June 8, 1962, appcal docketed, No. 380, Jan. 1962 Sess., Pa. Sup. Ct., July 17, 1962. 
constitutional right, the issue might be raised by a habeas corpus proceeding. But the time for raising the search and seizure question may be considered procedural. If so, then there is substantial authority that it is for state determination. The Supreme Court of the United States has said:

The Due Process Clause has never been perverted so as to force upon the forty-eight states a uniform code of criminal procedure. Except for the limited scope of the Federal criminal code, the prosecution of crimes is a matter for the individual States. The Constitution commands the states to assure fair judgment. Procedural details for securing fairness it leaves to the states. It is for them, therefore, to choose the methods and practices by which the crime is brought to book, so long as they observe those ultimate dignities of man which the United States Constitution assures. ${ }^{132}$

The doctrine that procedural questions remain for state determination may be carried over to the retroactive application of the exclusionary rule in $M a p p .{ }^{133}$

Relying on the edicts in Carter and Mapp that a state may decide its own procedural questions, the Pennsylvania Superior Court has refused to apply $M a p p$ in a number of situations on procedural grounds. Commonwealth ex rel. Marshall $v$. Maroney ${ }^{134}$ involved a petition for a writ of habeas corpus where the defendant sought to upset a judgment of conviction entered after a plea of guilty on the ground that narcotics found in his possession resulted from an illegal search and seizure. The Superior Court ruled that habeas corpus could not be used to challenge the legality of the conviction since the quality of the evidence was not in issue on the guilty plea. While not specifically set forth, the rationale may also be based, at least in part, on the principle that trial errors may be raised only on appeal and not by habeas corpus.

A somewhat different procedure was employed in Commonwealth v. Cuff,,$^{135}$ which concerned a petition to vacate a sentence on the ground that the defendant's arrest resulted from an illegal seizure of evidence. Ruling specifically that Mapp $v$. Ohio did not apply since there was no allegation that the illegally seized evidence was the basis of the conviction, the court also implied that the search and seizure question was raised too late.

The Pennsylvania Superior Court has refused to apply $M a p p$ where the search and seizure question was not raised in post-trial mo-

132 Carter v. Illinois, 329 U.S. 173, 175 (1946).

133 See generally Bender, The Retroactive Effect of an Overruling Constitutional Decision: Mapp v. Ohio, 110 U. PA. L. Rev. 650 (1962).

$134198 \mathrm{~Pa}$. Super. 85 (1962).

$135196 \mathrm{~Pa}$. Super. 274, 175 A.2d 136 (1961). 
tions. In Commonwealth v. Clark, ${ }^{130}$ the search, seizure, trial and conviction occurred prior to June 19, 1961, the day Mapp was decided. Defendant made no pretrial motions attacking the validity of the search and seizure. At the trial, however, defense counsel made an oral motion to exclude narcotics on the ground they were obtained through an illegal search and seizure. The court denied the motion. After the defendant was convicted, post-trial motions in arrest of judgment and for a new trial were filed, but those motions raised no question concerning the evidence obtained through the alleged illegal search and seizure. The post-trial motions were dismissed by the Court of Quarter Sessions of Allegheny County in an opinion filed on July 18, 1961 which was followed by an effort by defense counsel on August 14, 1961 to raise again the search and seizure question. The effort was unsuccessful and on August 18, 1961 sentence was imposed from which an appeal was taken to the Superior Court.

Upholding the judgment, the Pennsylvania Superior Court squarely ruled that the question could not be considered on appeal because it was not properly raised in the court below. It has long been a firm procedural ruling by the Pennsylvania appellate courts that matters not raised by proper post-conviction motions cannot be invoked on appeal even though constitutional questions may be involved. The Superior Court specificaly held that $M a p p$ v. Ohio did not require a contrary conclusion since the question was essentially procedural.

There is a hint in the opinion of the Pennsylvania Superior Court in Commonwealth v. Campbell, ${ }^{137}$ that Mapp would be applied retroactively if the issue was properly raised in the trial court. At the trial, which occurred prior to June 19,1961 , the court had ruled that defense counsel could not cross-examine on the question of probable cause for the issuance of a search warrant. That ruling was assigned as error in light of the Mapp decision which intervened between trial and appeal. The Superior Court held that there was no error, but stated:

This contention would be meritorious if illegality in obtaining the search warrant had been shown. However, there is nothing in the record to show illegality. During the course of the trial, counsel for defense in his cross-examination of the police officer who obtained the warrant, indicated that he was not attacking its legality but merely attempting to show bias . . . The questions of counsel elicited no showing of illegality . . . ${ }^{138}$

$136198 \mathrm{~Pa}$. Super. 64 (1962).

137196 Pa. Super. 380, 175 A.2d 324 (1961), petition for cert. filed. 30 U.S.L. WeEK 3376 (U.S. May 11, 1962) (No. 961).

$138 I d$. at 387.175 A.2d at 328. 
Implicit in the language is the suggestion that $M a p p$ might have been applied under that chronology had lack of probable cause been established at trial, or had defense counsel insisted on cross-examining on probable cause for the purpose of showing that the search and seizure were unlawful.

The issue of retroactive application of $M a p p$ was raised in a unique factual situation in Commonwealth $v$. Mancini, ${ }^{130}$ where a crucial date in the case history fell on the same day $M a p p$ was decided. After trial, which occurred prior to the Mapp decision, adjudication was deferred by the judge, sitting without a jury. On June 19, 1961-the same day the Supreme Court handed down the decision in $M a p p$-the defendant was found guilty. Motions for a new trial and in arrest of judgment were then filed on June 21, 1961, but it was not until October 13, 1961, that defendant's counsel sought to raise the illegality of the search and seizure which produced the evidence leading to the defendant's conviction. The trial court refused to consider the search and seizure question and denied the post-trial motions. The Court of Quarter Sessions of Philadelphia County also refused to apply the exclusionary rule on the ground that the trial was held prior to the Mapp decision, and defendant did not properly raise the constitutional issue since he failed to challenge the legality of the search warrants at trial. As this Article was going to press, the Superior Court affirmed this decision, holding that $M a p p$ is not to be applied retroactively. ${ }^{140}$

\section{Evaluation}

\section{A. The Effect of the Policy Debate on State Court}

\section{Implementation of Mapp}

Like many of its current decisions, the ruling of the Supreme Court of the United States in Mapp was based on considerations of public policy rather than on legal precedents. While it is virtually certain that the exclusionary rule will not soon be reversed regardless of the arguments advanced, its underlying policy considerations are important in analyzing the application of the doctrine by the state courts. It is to be expected that the application of a rule from which many dissent on policy grounds may be substantially different from the implementation of a law on which there is general agreement. 1962.

139 Nos. 317-23, Dec. 1960 Sess., Philadelphia County, Pa., Q. Sess., May 25,

140 No. 496, Pa Super. Ct, Sept. 13, 1962. In another case, the Court of Common Pleas of Philadelphia County squarely ruled that $M a p p$ is not retroactive. The Superior Court dismissed the appeal on the ground that the petition did not set forth substantial questions of fact or law. Commonwealth ex rel. Altizer v. Hendrick, No. 2392, Dec. 1961 Term, Philadelphia County, Pa., C.P., March 20, 1962, appeal dismissed, No. 262, Pa. Super. Ct., Sept. 13, 1962. 
State courts, especially those at the trial level, tend to place greater emphasis on law enforcement and community interest than on the protection of individuals' civil liberties. It is difficult to determine whether that approach was the parent or the child of the Supreme Court's greater stress on civil liberties. It may partially explain the initial reaction of the state courts to limit the exclusionary rule by liberally defining the scope of "reasonable" search and seizure. This inclination of the state courts to afford law enforcement officials latitude manifests an implicit conviction that the public welfare requires limitations on the Mapp doctrine. The state courts cannot repudiate $M a p p$, but they can take the broadest view of the bounds of reasonableness.

Some of the resentment to Mapp arises from the manner in which the exclusionary rule was imposed upon the states. The objection is frequently raised that a sudden change on such a fundamental evidentiary question is properly a legislative, rather than a judicial function. Congress and state assemblies are better equipped to hear evidence, weigh the relevant considerations, and express the will of the people on such a matter of public policy. This concept was cogently expressed by Judge Burton $R$. Laub, when he applied the Mapp doctrine in a criminal case in Erie County, Pennsylvania:

Even if it be conceded that the exclusionary rule is salutary, it is doubtful whether a constitutional provision should be made self-executing by the short form of amendment which Mapp used. If experience has demonstrated that civil remedies have been ineffectual to dissuade the police from illegal searches and seizures, this is a matter for the Congress and the State Legislatures to redress, for it is to these bodies that the lawmaking power has been delegated. If criminal or other sanctions should be adopted to implement the Constitution, the legislative branches of the government are adequately equipped with the power to do so. ${ }^{141}$

The procedure used by the Court is further subject to question since, as Justice Harlan's dissent states, the Court "reached out" to decide this question without full briefing and argument. ${ }^{142}$ However, in view of the plainly held views of the other justices, expressed in many prior decisions, it is highly improbable that the decision would have been different had a more appropriate case been awaited.

The state courts' reluctance to honor Mapp fully also stems from the deepseated conviction that the arguments against the exclusionary

141 Commonwealth v. Griffith, No. 294, May 1962 Sess., Erie County, Pa., Q. Sess., June 21, 1962, p. 2 n.3.

142367 U.S. at 674 (Harlan, J., dissenting). 
rule are still compelling, notwithstanding the Supreme Court's contrary conclusion. These jurists believe that the citizen's freedom was more secure before $M a p p$ than after; that it is more important to be free from the aggressive burglar, robber, and rapist than it is to be free from the aggressive policeman. From the local viewpoint, an innocent citizen on the street at night should be willing to suffer the personal inconvenience of being stopped and searched by a policeman if a similar search of the felon will save him from the much greater discomfort of being the criminal's next victim. In brief, the advantage of greater latitude for policemen in apprehending offenders outweighs the value of marginal protection of civil liberties. It is more important to convict the guilty than to prevent the unconstitutional search and seizure of the innocent which is only unpleasant. This is not to gainsay the strong arguments behind the $M a p p$ doctrine. Outrageous searches should be eliminated; and civil and criminal remedies may be ineffective against offending officers. A civil judgment is often uncollectible because the offending officer is execution-proof; criminal sanctions will seldom be initiated against the officer by other law enforcers. It is further contended that the courts and responsible law enforcement officers should not be a party to conduct which violates the Constitution. Police who enforce state laws can gather evidence without conducting unreasonable searches and seizures just as their federal counterparts have learned to do. Society will be ultimately benefited by elevating civil liberties over police powers. Like the contrary contentions, these arguments rest more on visceral reactions than on demonstrable evidence. Such absolute concepts, narrowmindedly urged by extremists on either side of the issue, create prejudice, not progress.

The assistant district attorney, who works closely with the police, is disposed to favor broader police powers. They make his job easier. The police, who have his ear, are outraged by the new law of search and seizure which makes their job so much more difficult. But in attempting an impartial evaluation, I would immediately reject the tendency of some $M a p p$ supporters to equate the policy of exclusion with the philosophy behind the presumption of innocence and the requirement that the prosecution prove its case beyond a reasonable doubt. The burden-of-proof rule and presumption of innocence are grounded on the often-repeated concept that it is better to let ten guilty men go free than to punish one innocent person. With this no one disagrees. The imprisonment of an innocent man is so repulsive a consequence that we would prefer to free many guilty men. But the same pulls are not generated by the search and seizure question. While it is unpleasant for an innocent citizen to be subjected to an unreasonable search and seizure, the consequence is not nearly so dire as sending an innocent 
man to jail. This difference should be kept in mind in evaluating the type of search and seizure which should be classified as "unconstitutional" so as to acquit the guilty.

The conflicting philosophies of search and seizure can probably be best reconciled by observing the strict mandate of $M a p p$, while allowing state courts substantial latitude in establishing standards of reasonableness. In that way the guilty will be acquitted only when they are victims of extreme searches, and there will be effective protection against reprehensible police practices. Civil liberties will be substantially elevated immediately, while the officer's latitude in conducting a search will be constricted gradually as police learn the subtleties of Mapp.

\section{B. The Cost of $M a p p$}

There can be no doubt that the Mapp decision has significantly impaired the ability of the police to secure evidence to convict the guilty. How detrimental this has been, however, is a matter of opinion rather than demonstrable fact. Unfortunately, it is impossible to determine with accuracy how much privacy has been promoted and how seriously police work has been hampered. It is my opinion that the police have been seriously handicapped by the exclusionary rule in the first year after $M a p p$. The right to privacy has not been significantly promoted during that time since the police have not fully understood and hence not fully complied with the Mapp rule. Initially, the only beneficiary has been the acquitted criminal. But in the future it is probable that altered police practices will enhance the right of privacy and the police should learn to function reasonably well within the confines of the exclusionary rule. Nevertheless, it is inevitable that Mapp will result in permanently eliminating some practices which have been effective against the criminal.

It is probable that many crimes are prevented by police in a city like Philadelphia by the "routine" car or person stop which so often results in the seizure of a fully loaded revolver in the hands of a man with a record of crimes of violence. The police ordinarily exercise discretion in making these stops by limiting them to nighttime in sections of the city where strongarm robberies are frequent. This type of preventive law enforcement is precluded by Mapp. The law abiding citizen who must walk on some Philadelphia streets at two o'clock in the morning would doubtless prefer to be subjected to a search, without any cause, and have the police do the same to the man standing idly at a corner; but that cannot be done under $M a p p$. Here again the best solution lies in liberal construction of what is a reasonable search and 
seizure, depending on factors which are well known to local judges, as well as local police.

\section{The Proper Application of Mapp}

The history of the exclusionary rule, policy considerations, and practical problems of law enforcement dictate that the state courts should be given extensive latitude in deciding what is a reasonable search and seizure. Mapp, which dealt with an admittedly unconstitutional seizure, held only that evidence must be excluded in a state criminal trial if it was unreasonably seized. The step-by-step approval from Weeks through Wolf to Irvine to Mapp shows that the Supreme Court deliberately did not impose on the states the federal standards of "reasonableness," but left that determination to the states, at least for the time being.

The major differences in law enforcement problems among the states support a policy that would allow the reasonableness of the seizure to be determined by local standards. Police problems also vary enormously within the same state. The problems in Philadelphia County are vastly different from those in Bradford County, Pennsylvania. At the Pennsylvania District Attorneys' Association Conference, held on July 9 through 11, 1962, most of the county prosecutors stated that they had not been confronted with a single problem on search and seizure in the year after the adoption of the exclusionary rule in Mapp. On the other hand, metropolitan areas like Pittsburgh and Philadelphia have been inundated with search and seizure questions.

At least until the police have an opportunity to absorb the subtleties of the exclusionary rule, law enforcement in the metropolitan areas requires that searches be justifiable upon a lesser showing of cause than that necessary to justify arrest. A search should be deemed constitutional if the officer has cause to suspect that the defendant has committed an offense. But Pennsylvania law provides that a misdemeanant can be arrested only if the officer saw him commit the offense. If $M a p p$ required the imposition of the federal rule that a search without a warrant must be incidental to a valid arrest, an officer who had not seen an offense committed would be precluded from searching an individual, even though he had good cause to believe that a misdemeanor had been perpetrated. Such a result is most undesirable in a large city with a crime problem. Nor should the search of a felon depend on whether the officer has reason to believe that the felony has been committed and this is the man. It should be sufficient for the officer to have some justifiable basis to suspect the defendant. Then, if the search reveals incriminating evidence, the defendant can be arrested. 
Similarly, the police should not be held to technical requirements on the contents of the search warrant. The essential question is whether the officer has probable cause to obtain the warrant, which information may be transmitted to the magistrate orally or in writing. The position that the officer must set forth in the warrant all the factors leading to the conclusion of probable cause is presumably asserted as the only way to test the officer's credibility. But honesty of the police and the ability of defense counsel to elicit the truth by cross-examination should be ample safeguards to insure credible testimony on probable cause. The problem of perjured testimony on this issue is certainly less substantial than the disadvantage of requiring that the police be expert draftsmen of the affidavit.

The fallacy in requiring great detail in the affidavit is illustrated by considering two opinions of the Court of Quarter Sessions of Philadelphia County which were handed down within a few days of each other in June, 1962. In Commonwealth $v$. Tanner, ${ }^{143}$ the court suppressed evidence because of insufficient facts in the affidavit despite its finding that the officers did in fact have probable cause to obtain the search warrant. In the case of Commonwealth $v$. Silverberg, ${ }^{144}$ the validity of the search and seizure without a warrant was upheld because the officer had probable cause to make the search, notwithstanding the fact that he had ample time to obtain a warrant before the search and seizure were made. On these rulings, an officer would be well advised to refrain from obtaining a warrant, and to set forth his probable cause at the time of the hearing on defendant's motion to suppress. Acting without a warrant, the officer would not be precluded from testifying as to the details of probable cause, whereas in Tanner, the officer was not permitted to augment the written affidavit with oral evidence. This anomalous consequence can easily be avoided by focusing on the essential question: did the officer have probable cause to obtain the warrant when he did so. Regardless of who has the burden of proving that the search and seizure were unreasonable, the officer should not be required to set forth details of his probable cause until the hearing on that question. If the burden lies on the defendant to prove the unconstitutionality of the search and seizure, then the absence of such oral testimony would result in the presumption of propriety attaching to the warrant.

The state courts should enjoy considerable latitude in interpreting the doctrine of consent, the range of validity of a warrant, and the permissible scope of a search. The authority of the state courts to

143 Nos. 2459-61, Jan. 1962 Sess., Philadelphia County, Pa., Q. Sess., June 21, 1962, appeal docketed, No. 321, Oct. 1962 Sess., Pa. Super. Ct., June 22, 1962.

144 No. 1586, April 1962 Sess., Philadelphia County, Pa., Q. Sess., June 18, 1962. 
establish their own procedural rules on issues such as the time for raising the search and seizure issue, retroactivity, and appellate procedures should likewise be respected.

\section{Conclusion}

Extrapolating from the history of constitutional controversy, it seems safe to predict that the Supreme Court, through the due process clause of the fourteenth amendment, will ultimately impose upon all the states uniform criminal procedures for important questions. As $M a p p$ has impressed the exclusionary rule upon all the states, a future decision will probably provide that all defendants in state criminal proceedings are entitled to counsel. In the long run such extensions of civil rights have generally proved beneficial.

The movement toward uniformity in state criminal proceedings has, however, serious disadvantages. The community pays a high price in less effective law enforcement by elevating the right of privacy over the police power. No empirical weights can be ascribed on the scales of justice to the values of civil liberties versus police power. In reconciling the two, over a year's experience with the exclusionary rule in a major metropolitan area teaches only that there is no confident conclusion.

While there must be changes in constitutional doctrine, long standing police practices should not be violently uprooted. State prosecution procedures should be accomodated to the greatest extent possible under the revised letter of the law. It is probable that the Supreme Court will ultimately impose fully federal standards for search and seizure on the states; but until the police have had a reasonable opportunity to absorb the subtleties of probable cause and the requisites of a warrant, the states should have the maximum degree of latitude in deciding what is a constitutional search and seizure. 